OPEN ACCESS

Approved by:

Alex Hansen,

Norwegian University of Science and

Technology, Norway

*Correspondence:

Frontiers Editorial Office

editorial.office@frontiersin.org

Specialty section

This article was submitted to

Mathematical and Statistical Physics,

a section of the journal

Frontiers in Physics

Received: 29 March 2021

Accepted: 30 March 2021

Published: 01 April 2021

Citation:

Frontiers Editorial Office (2021)

Retraction: Numerical Treatment for

3D Squeezed Flow in a Rotating Channel With Soret and Dufour

Effects. Front. Phys. 9:687508.

doi: 10.3389/fphy.2021.687508

\section{Retraction: Numerical Treatment for 3D Squeezed Flow in a Rotating Channel With Soret and Dufour Effects}

\section{Frontiers Editorial Office*}

\section{A Retraction of the Original Research Article}

Numerical Treatment for 3D Squeezed Flow in a Rotating Channel With Soret and Dufour Effects

by Alzahrani, A. K., Ullah, M. Z., and Muhammad, T. (2020). Front. Phys. 8:201. doi: $10.3389 /$ fphy.2020.00201

Following publication, concerns were raised regarding the flaws in the underlying physics, assumptions, and mathematical reasoning. An investigation was conducted in accordance with Frontiers guidelines and the authors failed to provide a satisfactory explanation.

This retraction was approved by the Chief Editors of Frontiers in Physics and the Editor-in-Chief of Frontiers. The authors did not agree to this retraction.

Copyright (0) 2021 Frontiers Editorial Office. This is an open-access article distributed under the terms of the Creative Commons Attribution License (CC BY). The use, distribution or reproduction in other forums is permitted, provided the original author(s) and the copyright owner(s) are credited and that the original publication in this journal is cited, in accordance with accepted academic practice. No use, distribution or reproduction is permitted which does not comply with these terms. 